\title{
A Comparative Evaluation of Acetylcholinesterase Inhibition by AChE-ICER and in vitro Ellman's Modified Method of Simplified Analogs 3-O-Acetyl-N-Benzyl-Piperidine of Donepezil
}

\author{
da Silva, J. I.; Nicastro, P. C.; de Oliveira, P. C. M.; Fossaluzza, P. C.; \\ Morais, E. P.; Dias, K. S. T.; da Costa, R. S.; Castro, N. G.; Cardoso, C. L.; \\ Viegas Junior, $\mathrm{C}^{*}$
}

Rev. Virtual Quim., 2015, 7 (6), 2334-2346. Data de publicação na Web: 3 de outubro de 2015

\section{http://www.uff.br/rvq}

\begin{abstract}
Avaliação comparativa da inibição de acetilcolinesterase por AChE-ICER e pelo método in vitro de Ellman modificado de análogos simplificados 3-O-acetil- $N$-benzilpiperidínicos do Donepezil
\end{abstract}

\begin{abstract}
Resumo: Inibidores de Acetilcolinesterase (AChEI) ainda são os melhores fármacos usados para a terapêutica da doença de Alzheirmer (DA). Dentre os IAChEs disponíveis, o donepezil apresenta a maior meia-vida, os efeitos colaterais mais brandos, além de segurança e tolerância satisfatórias; portanto, este tem sido utilizado como medicamento de primeira escolha no tratamento de DA leve a moderada. A triagem bem sucedida de novos AChEl depende de métodos rápidos e eficientes. Os ensaios empregados mais frequentemente são baseados no uso do reagente de Ellman (ensaio colorimétrico) ou do reagente Fast Blue B, além de métodos radioquímicos, espectrométricos ou cromatográficos. Uma abordagem mais recente utiliza a enzima imobilizada em reator capilar, acoplada a um sistema cromatográfico, que é conhecido como ICER (do inglês immobilized capillary enzyme reactor). Como parte de um projeto que visa à identificação de novos IAChEs, este artigo descreve a avaliação comparativa da atividade inibitória da AChE de uma série de derivados 3-O-acetil- $N$-benzilpiperidínicos substituídos por duas diferentes abordagens: método de Ellman modificado in vitro e uma metodologia de ICER. Embora nenhum dos compostos da série tenha apresentado alta atividade inibitória, todos os ensaios revelaram resultados consistentes, demostrando que é possível aplicar diferentes metodologias confiáveis para a busca e idendificação de novos inibidores de AChE.
\end{abstract}

Palavras-chave: Química Medicinal; análogos N-benzil-piperidinícos; inibidores de acetilcolinesterase; doença de Alzheimer; enzima imobilizada; enzima imobilizada em reator capilar.

\begin{abstract}
Acetylcholinesterase inhibitors (AChEI) remain the best pharmacotherapy for Alzheimer's disease (AD). Among the currently available AChEI drugs, Donepezil has longer half-life, fewer clinical side interactions, and satisfactory safety and tolerability; therefore, it is the first choice medicine to treat mild to moderate AD. Successful screening for new AChEls relies on effective and fast assays. The most frequently employed assays are based on the use of Ellman's reagent (colorimetric method) or the Fast Blue B salt reagent, despite of other radiochemical, spectrometric, or chromatographic methods. A more recent and interesting approach is to immobilize the target enzyme in a chromatographic system, which is known as immobilized capillary enzyme reactors (ICERs). As part of a current project aiming to search for novel AChEls, in this paper we have reported a comparative evaluation of AChE inhibitory activity of a series of substituted 3-O-acetyl- $N$-benzylpiperidine derivatives by two different approaches: in vitro Ellman's modified method and an ICER-based methodology. Although none of the compounds has shown high activity, all different assays revealed consistent results, showing that is possible to apply different reliable methodologies for the screening of new AChEls.
\end{abstract}

Keywords: N-benzyl-piperidine analogs; Acetylcholinesterase inhibition; Alzheimer's Disease; enzyme immobilization; immobilized capillary enzyme reactor.

\footnotetext{
* Universidade Federal de Alfenas, Instituto de Química, Laboratório de Fitoquímica e Química Medicinal, CEP 37130-000, AlfenasMG, Brasil..

Mcvjviegas@gmail.com

DOI: $\underline{10.5935 / 1984-6835.20150139}$
} 


\section{A Comparative Evaluation of Acetylcholinesterase Inhibition by AChE-ICER and in vitro Ellman's Modified Method of Simplified Analogs 3-O-Acetyl-N-Benzyl-Piperidine of Donepezil} Joyce Izidoro da Silva, ${ }^{a}$ Patrícia Carolina Nicastro, ${ }^{b}$ Patrícia C. M. de Oliveira, ${ }^{\mathrm{b}}$ Poliana C. Fossaluzza, ${ }^{\mathrm{b}}$ Élida P. Morais, ${ }^{\mathrm{b}}$ Kris Simone T. Dias, ${ }^{\mathrm{b}}$ Rodrigo S. da Costa, ${ }^{\mathrm{C}}$ Newton G. Castro, ${ }^{\mathrm{C}}$ Carmen Lúcia Cardoso, ${ }^{\mathrm{a}}$ Claudio Viegas Jr. ${ }^{b *}$

a Universidade de São Paulo, Faculdade de Filosofia, Ciências e Letras de Ribeirão Preto, Departamento de Química, Ribeirão Preto-SP, Brasil.

${ }^{\mathrm{b}}$ Universidade Federal de Alfenas, Instituto de Química, Laboratório de Fitoquímica e Química Medicinal, CEP 37130-000, Alfenas-MG, Brasil.

' Universidade Federal do Rio de Janeiro, Instituto de Ciências Biomédicas, Departamento de Farmacologia Básica e Clínica, CCS Bloco J Sala J1-029, CEP 21941-902, Rio de Janeiro-RJ, Brasil.

\section{*cvjviegas@gmail.com}

Recebido em 30 de março de 2015. Aceito para publicação em 29 de setembro de 2015

\section{Introduction}

\section{Experimental}

2.1. Chemistry

2.2. Biological Assays

\section{Results and discussion}

4. Conclusion

\section{Introduction}

Alzheimer's Disease (AD) is an incurable neurodegenerative condition. It is the most common type of dementia among the elderly and affects over 36 million people worldwide. ${ }^{1}$ Three main hypotheses, the socalled cholinergic, amyloid, and the tau hypothesis, have been proposed to explain the pathophysiology of $\mathrm{AD}^{2,3}$ The main factors associated with $A D$ is the low level of acetylcholine in the neural synapses, deposits of senile plaques and neurofibrillary tangles in the barin tissue, a severe neuroinflammatory process and neuronal death. ${ }^{2-6}$ Deficits in the brain cholinergic system contribute to cognitive dysfunction in $A D .^{4-6}$

Due to the multifactorial characteristics this disease, many researchers have conducted studies on natural products and synthetic new compounds searching for more effective and secure drug prototypes, on the 
basis of the cholinergic and amyloid hypotheses and, more recently, antioxidant, anti-inflammatory and/or neuroprotective therapies. ${ }^{7-9}$ This new way of "thinking" bioactive compounds that act on different target simultaneously is based on the modern concept of multi-target directed ligands (MTDLs). ${ }^{10,11}$ In particular, cognitive deficits have led to the development of cholinergic strategies, aiming the improvement of cholinergic function and this approach led to most of the medicines used today.

Acetylcholinesterase (AChE) is a serine hydrolase enzyme that catalyzes the hydrolysis of the neurotransmitter acetylcholine. The main medications that treat $A D$ symptoms belong to the class of cholinesterase inhibitors (ChEls). Indeed, among the five commercially available drugs to treat AD, Tacrine, Donepezil, Rivastigmine, and Galanthamine, are AChE inhibitors (AChEl), whereas memantine is an NMDA receptor antagonist. Unfortunately, all of these medicines are only palliative, bringing on unwanted side effects, and their effectiveness diminishes after prolonged treatment. ${ }^{4}$ Donepezil, approved by the FDA in 1996, is a reversible and highly selective AChEl. It is well-tolerated and displays a side effect profile typical of cholinergic agents, with minimal influence on the hepatic and renal impairment that is common in the elderly population. Moreover, Donepezil has a long half-life, which allows the use of lower doses, less frequent and smaller variation of drug concentrations in plasma. Furthermore, donepezil has few clinical side interactions, and adequate safety and tolerability. Thus, it is usually the first choice medicine to treat mild to moderate $A D .^{10-12}$

As part of an ongoing project on the search for novel anti-Alzheimer drug candidate prototypes, we have reported the design and synthesis of new series of AChEls based on molecular simplification of donepezil ${ }^{13}$, preserving the common pharmacophoric substituted piperidine moiety present in donepezil (1) and the AChE inhibitor

(-)-3-0-acetyl-spectaline

hydrochloride

(LASSBio-767

(2)), a

semisynthetic derivative of the natural (-)spectaline ${ }^{14,15}$ taken as structural models ( $A$ and $B$, Figure 1 ). Considering that choosing appropriate assay is crucial when assessing the inhibitory activity of a given compound, we decide to use these series of simple small molecules for a comparative study, using the most common and fast methods describe in the literature for AChE activity identification.

In the past years, several methods to determine AChE activity has been described. ${ }^{16}$ The most frequently employed solution enzyme assays rely on a colorimetric method using Ellman's reagent ${ }^{17}$ or the Fast Blue $B$ salt reagent, and also on radiochemical, spectrometric, and chromatographic methods ${ }^{16,18}$ and capillary electrophoresis. ${ }^{19-20}$ Other methods involve an interesting approach: the immobilization of the target enzyme and its inclusion in a chromatographic system. Such methods can provide a shorten analysis and more reliable results, besides furnishing information about the affinity of the tested molecule for the target protein. Therefore, they could allow for the online determination of a compound inhibitory potency as well as help getting information about the possible enzyme inhibition mechanism. ${ }^{21,22}$ In this context, various authors have immobilized AChE onto different supports, by different immobilization methods. ${ }^{22-31}$ Our group has contributed a previous paper on the development and application of ChEls screening methodologies using ICER-AChE and UV detection, ${ }^{22}$ and also reported a direct method using AChE-ICER and LC/IT$\mathrm{MS} / \mathrm{MS}^{31}$

In the present work, we have used a series of substituted 3-O-acetyl- $\mathrm{N}$-benzylpiperidine derivatives (3, Figure 1$)^{13}$ for evaluation of their activity by an ICER- based screening methodology $\mathrm{y}^{22}$ in comparison to inhibitory data displayed on the in vitro Ellman's modified method, ${ }^{14,17}$ and even by the classical qualitative TLC assays. ${ }^{16,33,34}$ 


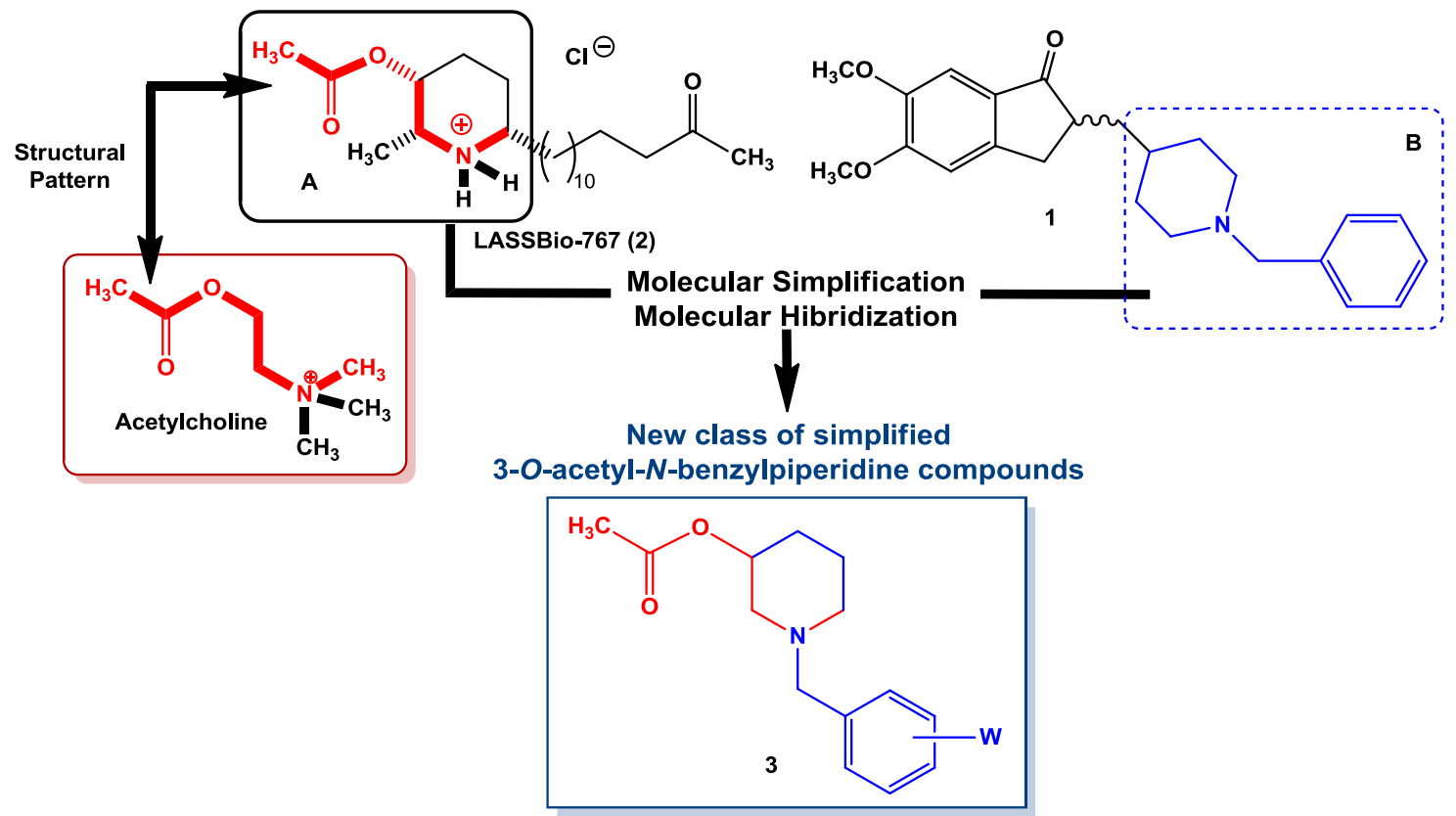

Figure 1. Design of a series of 3-O-acetyl- $N$-benzylpiperidine derivatives (3) based on the structures of Donepezil (1) and the selective AChEI LASSBio-767 (2)

\section{Experimental}

\subsection{Chemistry}

${ }^{1} \mathrm{H}$ and ${ }^{13} \mathrm{C}$ NMR spectra were determined in chloroform-d3 and methanol-d4 with a Varian INOVA 500 spectrometer at 500 and $125 \mathrm{MHz}$, respectively. IR spectra were obtained with a Nicolet-1400 FTIR spectrometer using $\mathrm{KBr}$ pellets. Prior to concentration under reduced pressure, all the organic extracts were dried over anhydrous magnesium sulfate powder. The progress of all the reactions was monitored by TLC performed on aluminum sheets precoated with silica gel (F-254, Merck) and viewed by spraying with iodochloroplatinate reagent (Merck). Purifications by column chromatography were performed with silica gel (70-230 mesh, Merck). Solvents used in the reactions were dried, redistilled prior to use, and stored over 3-4 $\mathrm{A}^{\circ}$ molecular sieves.

\section{Preparation of 3-O-acetyl-piperidine}

To a solution containing $406.0 \mathrm{mg}(3.96$ $\mathrm{mmol}$ ) of 3-hydroxypiperidine in hexane (6.5 $\mathrm{mL}), 24.6 \mathrm{mg}(0.202 \mathrm{mmol})$ of 4-DMAP and $0.37 \mathrm{~mL}(4.04 \mathrm{mmol})$ of acetic anhydride were added. The mixture was vigorously stirred at room temperature for $72 \mathrm{~h}$ until TLC analysis indicated that reaction was complete. Then, the solvent was evaporated under vaccum, and the crude product was purified by silica gel column chromatography eluted with $\mathrm{CH}_{2} \mathrm{Cl}_{2}$ : MeOH 9:1, to furnish $441.3 \mathrm{mg}$ of a pale yellow oil ( $85 \%$ yield). The structure of the 3-O-acetyl-piperidine was confirmed by IR spectrometry.

General procedure for preparation of compounds $\mathbf{3 a}-\boldsymbol{r}$ and $\mathbf{3 x}$

To a solution of 3-O-acetylpiperidine (1.05 $\mathrm{mmol})$ in anhydrous methanol $(5 \mathrm{~mL}), 1.05$ mmol of the substituted aldehyde was added. Then, the $\mathrm{pH}$ was adjusted to 6 with acetic acid, and the reaction was vigorously stirred at room temperature, for $48 \mathrm{~h}$. After this time, $1 \mathrm{mmol}$ of the starting amine was added and the reaction mixture was stirred overnight. After $72 \mathrm{~h}, \mathrm{NaBH}_{3} \mathrm{CN}$ (6 mmol) was 
added, and the reaction was stirred overnight at room temperature. After the reaction was completed as judged from (TLC), a $10 \%$ sodium phosphate solution $(5 \mathrm{~mL})$ and water $(5 \mathrm{~mL})$ were added, and the crude product was extracted with $\mathrm{CH}_{2} \mathrm{Cl}_{2}(3 \times 10 \mathrm{~mL})$. The organic phases were combined, washed with saturated $\mathrm{NaCl}$ solution, and dried over $\mathrm{MgSO}_{4}$. The solvent was removed, and the crude product was purified by silica gel column chromatography eluted with $\left(\mathrm{CH}_{2} \mathrm{Cl}_{2}\right.$ : $\mathrm{MeOH}$ 9:1), to furnish the desired 3-Oacetylpiperidinylbenzyl derivatives in $60-90 \%$ yield. To prepare derivative $\mathbf{3 x}$, compound $\mathbf{3 k}$ was reacted with anhydrous $\mathrm{HCl}$ in $\mathrm{AcOEt}$, to furnish the desired chloridrate in quantitative yield. The structures of all the compounds were confirmed by ${ }^{1} \mathrm{H}$ and ${ }^{13} \mathrm{C} N M R$ and compared with literature data.

\subsection{Biological Assays}

\section{Reagents and Materials}

Acetylcholinesterase (AChE, EC 3.1.1.7, from Electric eel, 333 units/MG, and from human Erythrocytes) lyophilized powder and its substrate (S)-acetylthiolcholine iodide (ATCh); 5,5'-Dithiobis (2-nitrobenzoic acid) (Ellman's reagent or DTNB); tacrine (9-amino1,2,3,4-tetrahydroacridine hydrochloride hydrate), Fast Blue B salt (O-dianisidinebis(diazotized) hydrochloride zinc double salt), $\beta$-naphthyl acetate, and glutaraldehyde were supplied by Sigma-Aldrich. Buffer components, and all the chemical materials used during the immobilization procedure were of analytical grade and were purchased from Sigma, Merck (Darmstdt, Germany), Synth (São Paulo, Brazil), or Acros (Geel, Belgica). Water employed in all the experiments had been purified in a Millipore Milli-Q system (Millipore, São Paulo, Brazil). Fused silica capillary $(0.375 \mathrm{~mm} \times 0.10 \mathrm{~mm})$ was acquired from Polymicro Technologies (Phoenix, AZ, USA). The entire buffer solutions were filtered through cellulose nitrate membrane filters $(0.45 \mu \mathrm{m})$ provided by Phenomenex. Stock solutions $(10 \mathrm{mM})$ of the evaluated inhibitors were prepared in water/methanol $[(50 \%(\mathrm{v} / \mathrm{v})]$ and diluted with water, to give concentrations in the range of $10-1000 \mu \mathrm{M}$. Silica gel plates (silica gel 60 $F_{245}$ ) aluminum sheets were provided by Merck (Darmstadt, Germany).

\section{Apparatus}

Enzyme immobilization was carried out by using a syringe-pump 341B (Sage instruments, Boston, USA). The AChE-ICER was placed in a Shimadzu HPLC system (Shimadzu, Kyoto, Japan) consisting of two LC 20AD pumps. One of the pumps contained an FCV-20AL valve for low-pressure gradient, a UV-Vis detector (SPD-M20AV), an autosampler equipment (SIL-20A), and a sixport and three-way switching sample valve Valco. Data acquisition was accomplished on a Shimadzu CBM-20A system interfaced with a computer, using the Shimadzu-LC Solutions (LC Solution 2.1) software (Shimadzu, Kyoto, Japan). A microplate reader system (Elisa readers) Versa Max-Molecular Device (Silicon Valley, CA, USA) was employed in the assays involving the free enzyme in solution.

\section{Buffer}

Buffer 1: $0.1 \mathrm{M}$ Tris-HCl (pH 8.0) $1.26 \times 10$ ${ }^{4} \mathrm{M}$ Ellman's reagent designated working buffer and used as the mobile phase for all the chromatographic systems, in all the experiments employing the AChE-IMER.

\section{AChE columns preparation}

Columns were prepared by a protocol described in our previous reports ${ }^{22}$ by using a solution containing $0.5 \mathrm{mg}$ of AChE (approximately $150 \mathrm{U}$ ) in $50 \mathrm{mM}$ phosphate buffer ( $\mathrm{pH}$ 8.0) and fused-silica capillary tube $(100 \mu \mathrm{m} \mathrm{I.D} \times 0.375 \mathrm{~mm} \times 30 \mathrm{~cm})$. 
Screening studies by using AChE-ICER assay

All compounds $\mathbf{3 a}-\mathbf{3 x}$ were evaluated using the method described in our previous report. ${ }^{22}$ To this goal, a $1 \mathrm{mM}$ stock solution $\left(\mathrm{MeOH} / \mathrm{H}_{2} \mathrm{O}\right.$ 1:1 v/v) was prepared for each inhibitor. For analytical purposes, a sample with a final volume of $100 \mu \mathrm{L}$ was obtained by using $20 \mu \mathrm{L}$ of the inhibitor stock solution, $20 \mu \mathrm{L}$ of ATCh solutions ( $5 \mathrm{mM})$, and $60 \mu \mathrm{L}$ of Buffer 1 , which resulted in a concentration of $200 \mu \mathrm{M}$ for the candidate compound and 1 $\mathrm{mM}$ for ATCh in Buffer 1. The samples were prepared in duplicate, and $10-\mu \mathrm{L}$ aliquots were injected into the chromatographic system using the following conditions: mobile phase consisting of Buffer 1, flow rate $=0.05$ $\mathrm{mL} . \mathrm{min}^{-1}$, and UV-Vis detection at $412 \mathrm{~nm}$. The percent inhibition obtained for each compound was calculated by comparing the attained peak areas with the area achieved for the YA (yellow anion) when a sample containing water and substrate ATCh $(1 \mathrm{mM})$ was injected into the chromatographic system under the same operating conditions. The percentage inhibition for each inhibitor concentration was calculated by comparing the peak areas with those obtained in the absence of the inhibitor. To this end, the following expression was employed: 100$\left(\mathrm{Ai} / \mathrm{A}_{0} \times 100\right)$, where $A_{i}$ is the peak area calculated in the presence of the inhibitors, and $A_{0}$ is the peak area calculated in the absence of the inhibitors.

TLC and microplate assay using Ellman's method

The inhibitory activity of compounds 3a$3 \mathbf{x}$ was determined by using Ellman's reagent either via a TLC assay or a microplate assay, as previously described. ${ }^{17,34}$

TLC assay using Fast Blue B salt as reagent

The inhibitory activity of compounds 3a3x was also evaluated with a TLC assay using Fast Blue $B$ salt as reagent as previously described. ${ }^{18}$

False positive assay (Chemical reaction of thiocholine and DTNB)

To verify whether the positive results shown by compounds in the TLC or microplate assay was not due to inhibition of the chemical reaction between DTNB and the product of the enzyme reaction (thiocholine), a false positive assay was performed as previously described. ${ }^{34}$

\section{Results and discussion}

The target compounds 3a-x were prepared in two steps from commercial 3hydroxypiperidine (4) by reaction with $\mathrm{Ac}_{2} \mathrm{O} / 4$-DMAP in hexane, to produce the corresponding piperidine acetate 5 . In a second step, compound $\mathbf{5}$ was submitted to reductive amination reactions with several substituted benzaldehydes in the presence of $\mathrm{NaBH}_{3} \mathrm{CN}$ to furnish the desired substituted 3-O-acetyl- $N$-benzylpiperidines (3a-v) in 60$89 \%$ yields (Figure 2, Table 1 ). Compound $\mathbf{3 x}$ was obtained by reaction of the amino derivative $3 \mathbf{k}$ with anhydrous $\mathrm{HCl}$ in a quantitative yield (Figure 3, Table 1). 
HO<smiles>CC1CCCNC1</smiles>

4

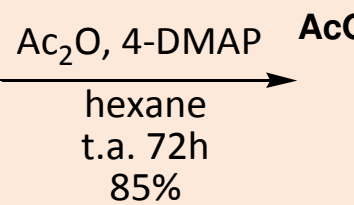

$85 \%$<smiles>OC1CCCNC1</smiles>

5

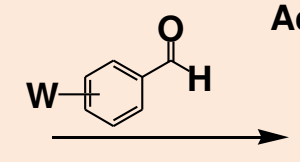

$\mathrm{NaBH}_{3} \mathrm{CN}, \mathrm{MeOH}$ $\mathrm{pH} 5,80 \stackrel{\circ}{ } \mathrm{C}, 72 \mathrm{~h}$

$60-89 \%$

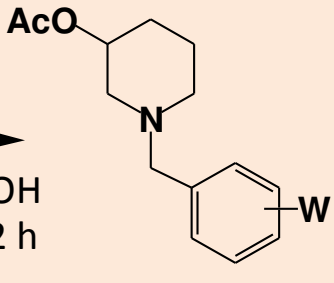

3a-v

Figure 2. General synthetic route for the preparation of the substituted 3-O-acetyl- $N$ benzylpiperidine derivatives 3a-v

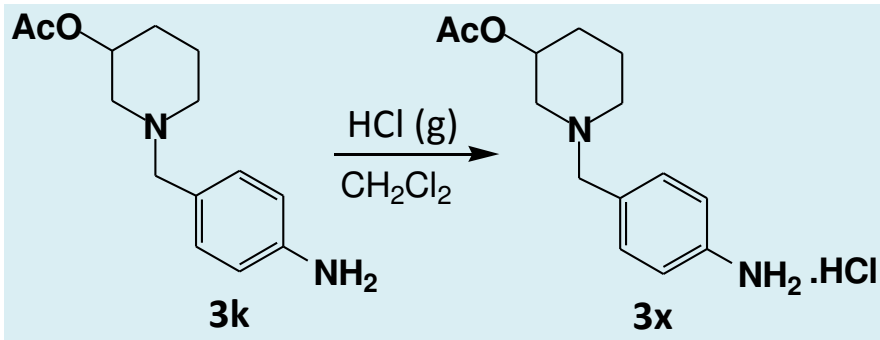

Figure 3. General synthetic route for the preparation of the substituted 3-O-acetyl- $N$ benzylpiperidine derivatives $\mathbf{3 x}$

Table 1. Structural and chemical data for compounds 3a-x

\begin{tabular}{|c|c|c|c|}
\hline Compound & Code & $\mathbf{W}$ & Yield (\%) \\
\hline $3 a$ & LFQM-03 & 3,4-di-OH & 63 \\
\hline $3 b$ & LFQM-04 & $4-\mathrm{Cl}$ & 65 \\
\hline $3 c$ & LFQM-05 & $4-F$ & 64 \\
\hline $3 d$ & LFQM-06 & $4-\mathrm{OH}$ & 60 \\
\hline $3 e$ & LFQM-07 & $4-\mathrm{Br}$ & 76 \\
\hline $3 f$ & LFQM-08 & 3,4-di-OCH & 70 \\
\hline $3 g$ & LFQM-09 & $3-\mathrm{OCH}_{3}, 4-\mathrm{OH}$ & 56 \\
\hline $3 \mathbf{i}$ & LFQM-11 & $3-\mathrm{OCH}_{3}$ & 66 \\
\hline $3 \mathbf{j}$ & LFQM-12 & $4-\mathrm{NO}_{2}$ & 80 \\
\hline $3 k$ & LFQM-13 & 4- $\mathrm{NH}_{2}$ & 64 \\
\hline 31 & LFQM-14 & $4-\mathrm{CF}_{3}$ & 78 \\
\hline $3 m$ & LFQM-15 & $4-\mathrm{N}\left(\mathrm{CH}_{3}\right)_{2}$ & 61 \\
\hline $3 n$ & LFQM-16 & $3,4-\mathrm{OCH}_{2} \mathrm{O}-$ & 60 \\
\hline 30 & LFQM-17 & $\mathrm{H}$ & 90 \\
\hline $3 p$ & LFQM-28 & $3-\mathrm{OH}, 4-\mathrm{OCH}_{3}$ & 58 \\
\hline $3 q$ & LFQM-37 & $3-\mathrm{OH}$ & 60 \\
\hline $3 r$ & LFQM-38 & $4-\mathrm{OCH}_{3}$ & 72 \\
\hline 3s & LFQM-40 & 4-(1-morpholyl) & 89 \\
\hline $3 t$ & LFQM-41 & 4-(1-piperidinyl) & 81 \\
\hline $3 u$ & LFQM-42 & 4-(1-pirrolidinyl) & 75 \\
\hline $3 v$ & LFQM-43 & 4- $\mathrm{SCH}_{3}$ & 65 \\
\hline $3 x$ & LFQM-70 & $4-\mathrm{NH}_{2} \cdot \mathrm{HCl}$ & 100 \\
\hline
\end{tabular}


Choosing an appropriate screening assay to evaluate AChE inhibition or other biological activity is crucial. Indeed, the results of biological activities obtained by different assays and/or by different research groups can vary considerably. ${ }^{35-37}$ Here, we evaluated the inhibitory activities of the 22 compounds of the series $\mathbf{3}$ against AChE by two different methods aiming to establish a qualitative comparison. To this goal, we used the classical in vitro methodology based on the modified Ellman's test, which data are displayed on Figure 4, and a method based on AChE-ICER bioreactor prepared by immobilization of AChE onto fused silica capillaries $^{22}$ as LC column for online studies, with UV-Vis detection (Table 2).

The results achieved for the majority of the compounds were consistent in both methods, revealing a comparable same order of AChE inhibitory activity for most of compounds. For some, the numeric values varied depending on the evaluation method. Furthermore, both methodologies also serve to evidence that the absence of the 3,4dimethoxyindanone subunit of donepezil, is not vital for an AChE inhibitory profile. In fact, the singular structural pattern of donepezil attribute good drug ability properties, but the preservation of the substituted piperidine moiety seems to be sufficient to achieve a significant inhibitory profile, as observed for the piperidine alkaloid LASSBio-767 (2). Considering literature data, these findings were not surprising, because AChE recognizes donepezil by interactions including the middle gorge of the active site of the enzyme, which involves three subunits: the benzyl moiety, the nitrogen atom on the piperidine ring, and the dimethoxy-indanone portion. These interactions involve direct contacts mediated by water molecules, which seem to be crucial for binding and specificity. Some studies with other donepezil analogs evidenced that the presence of two aromatic functional groups in the structure of the inhibitor is also important. These aromatic subunits probably play an essential role in $\pi$ $\pi$ stacking interactions with the aromatic residues Trp84 and Trp279 located in the peripheral regions of the AChE gorge. ${ }^{38}$

Thus, it is possible to explore simplified donepezil analogs with preserved $\mathrm{N}$ benzylpiperidine pharmacophoric subunit for structure-activity studies, and to establish rational comprehensive contributions of the different substituents on the aromatic ring to the potency and selectivity of AChE inhibitors. Here, the in vitro evaluation revealed that compounds LFQM-06 (3d), LFQM-08 (3f), LFQM-12 (3j), and LFQM-38 (3r) were the most active, exhibiting AChE inhibitory effects of 27.88, 22.79, 21.32 and $21.53 \%$, respectively, in comparison to the prototype LASSBio-767 (2) at a dose of 100 $\mu \mathrm{M}$ (Figure 4).

According to Table 2, the method in vitro Ellman's test was capable to identified compounds $\mathbf{3 d}, \mathbf{3 e}, \mathbf{3 f}, \mathbf{3 p}$ and $\mathbf{3 r}$ as the most active of the series. In order to evaluate the selectivity of the target compounds toward AChE of different origins, we prepared two AChE-ICERs by using AChE from Electrophohus electricus (ee-AChE-ICER-) and AChE from human erythrocytes (hu-AChEICER). Again, the results depicted in Table 2 demonstrated weaker inhibitory activity for all compounds, in comparison to LASSBio767, but in this test compound LFQM-70 (3x) afforded the highest inhibitory activity (56\%). Considering the selectivity toward hu-AChE and ee-AChE, compounds 3a (32.4\%), 3b (28.7 \%) and $3 \times$ (56.0 \%) were more selective for hu-AChE-ICER, whereas compound $\mathbf{3 u}$ showed higher selectivity for ee-AChEI-CER. 


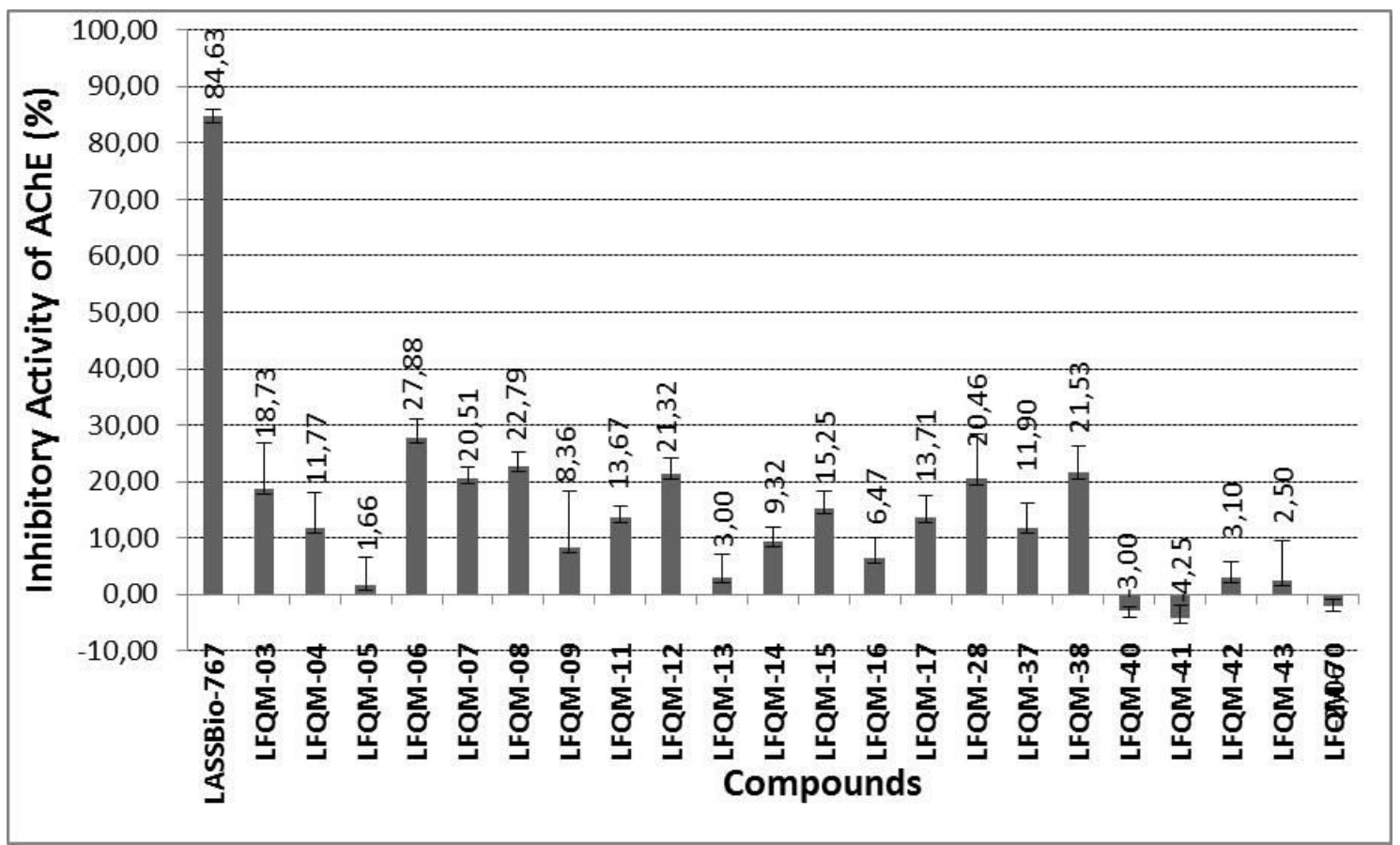

Figure 4. Inhibitory activity of AChE data obtained by the modified Ellman's test

Table 2. Comparative AChE inhibitory data of compounds 3a-3x in different screening tests

\begin{tabular}{|c|c|c|c|c|c|c|c|c|}
\hline \multirow{2}{*}{\multicolumn{2}{|c|}{ Compound }} & \multicolumn{3}{|c|}{ TLC assays } & \multirow{2}{*}{$\begin{array}{c}\text { Microplat } \\
\text { e assay } \\
(200 \mu \mathrm{M})\end{array}$} & \multirow{2}{*}{$\begin{array}{c}\text { ee-AChE } \\
\text { ICER } \\
(200 \\
\mu \mathrm{M}) \\
\\
(\%)\end{array}$} & \multirow{2}{*}{$\begin{array}{c}\begin{array}{c}\text { huAChE } \\
\text { ICER } \\
(200 \mu \mathrm{M})\end{array} \\
(\%)\end{array}$} & \multirow{2}{*}{$\begin{array}{c}\text { In vitro } \\
\text { Ellman's } \\
\text { method } \\
(100 \mu \mathrm{M}) \\
(\%)\end{array}$} \\
\hline & & $\begin{array}{l}\text { Ellman's } \\
\text { method }^{a}\end{array}$ & $\begin{array}{c}\text { False } \\
\text { positive }^{b}\end{array}$ & $\begin{array}{c}\text { Fast Blue B } \\
\text { salt as } \\
\text { reagent }^{c}\end{array}$ & & & & \\
\hline $\begin{array}{c}\text { Tacrin } \\
\mathrm{e}^{*}\end{array}$ & Tacrine ${ }^{*}$ & +++ & - & +++ & 90.0 & 93.1 & 90.0 & --- \\
\hline $3 a$ & $\begin{array}{c}\text { LFQM- } \\
03\end{array}$ & + & - & + & 11.2 & 16.4 & 32.40 & 18.73 \\
\hline $3 b$ & $\begin{array}{l}\text { LFQM- } \\
04\end{array}$ & + & - & + & 11.2 & 16.3 & 28.72 & 11.77 \\
\hline $3 c$ & $\begin{array}{l}\text { LFQM- } \\
05\end{array}$ & + & - & + & 14.8 & 0 & 3.51 & 1.66 \\
\hline $3 d$ & $\begin{array}{l}\text { LFQM- } \\
06\end{array}$ & + & - & + & 11.4 & 14.5 & 4.01 & 27.88 \\
\hline $3 e$ & $\begin{array}{c}\text { LFQM- } \\
07 \\
\end{array}$ & + & - & + & 7.1 & 26.2 & 3.37 & 20.51 \\
\hline $3 f$ & $\begin{array}{c}\text { LFQM- } \\
08 \\
\end{array}$ & + & - & + & 23.0 & 23.7 & 14.55 & 27.79 \\
\hline $3 g$ & $\begin{array}{l}\text { LFQM- } \\
09 \\
\end{array}$ & + & - & + & 31.5 & 24.5 & 13.33 & 8.36 \\
\hline $3 \mathbf{i}$ & $\begin{array}{c}\text { LFQM- } \\
11\end{array}$ & + & - & + & 21.8 & 0 & 4.06 & 13.6 \\
\hline $3 \mathbf{j}$ & $\begin{array}{c}\text { LFQM- } \\
12 \\
\end{array}$ & + & - & + & 31.6 & 12.6 & 0.7 & 21.3 \\
\hline
\end{tabular}

Rev. Virtual Quim. |Vol $7 \mid$ | No. 6 | |2334-2346| 


\begin{tabular}{|c|c|c|c|c|c|c|c|c|}
\hline $3 k$ & $\begin{array}{c}\text { LFQM- } \\
13 \\
\end{array}$ & + & - & + & 19.3 & 0 & 3.79 & 3.0 \\
\hline 31 & $\begin{array}{c}\text { LFQM- } \\
14 \\
\end{array}$ & + & - & + & 22.8 & 21.5 & 2.25 & 9.32 \\
\hline $3 m$ & $\begin{array}{c}\text { LFQM- } \\
15\end{array}$ & + & - & + & NT & 0 & 7.76 & 15.25 \\
\hline $3 n$ & $\begin{array}{c}\text { LFQM- } \\
16\end{array}$ & + & - & + & 25.9 & 24.1 & 1.7 & 6.47 \\
\hline 30 & $\begin{array}{c}\text { LFQM- } \\
17\end{array}$ & + & - & + & NT & 0.20 & 0.20 & 13.71 \\
\hline $3 p$ & $\begin{array}{c}\text { LFQM- } \\
28\end{array}$ & + & - & + & 32.8 & 16.2 & 10.5 & 20.46 \\
\hline $3 q$ & $\begin{array}{c}\text { LFQM- } \\
37\end{array}$ & + & - & + & 38.6 & 22.3 & 6.6 & 11.90 \\
\hline $3 r$ & $\begin{array}{c}\text { LFQM- } \\
38\end{array}$ & + & - & + & NT & 21.46 & 1.2 & 21.53 \\
\hline $3 s$ & $\begin{array}{c}\text { LFQM- } \\
40\end{array}$ & + & - & + & 0 & 0 & 0 & 3.0 \\
\hline $3 t$ & $\begin{array}{c}\text { LFQM- } \\
41\end{array}$ & + & - & + & 45.8 & 18.6 & 2.6 & 4.25 \\
\hline $3 u$ & $\begin{array}{c}\text { LFQM- } \\
42\end{array}$ & + & - & + & NT & 45.1 & 2.6 & 3.10 \\
\hline $3 v$ & $\begin{array}{c}\text { LFQM- } \\
43\end{array}$ & + & - & + & 0 & 0 & 0 & 2.5 \\
\hline $3 x$ & $\begin{array}{c}\text { LFQM- } \\
70\end{array}$ & + & - & + & 49.1 & 41.7 & 56.0 & 0 \\
\hline
\end{tabular}

\section{Conclusion}

Screening assays on the AChE inhibitory activity are suitable to identify new potential drugs. The AChE-ICER assay is appropriate and a fast alternative method for screening libraries of compounds and enables automation and easy handling of large amounts of samples. Although the collection assessed here afforded only weak AChEls that was prepared as chemical intermediates, structure-activity information from the biological assays could be useful for guiding the design and synthesis of more efficient donepezil-based AChEls with innovative structural patterns and also help researchers to choose the most adequate method for biological screening.

\section{Acknowledgments}

The authors gratefully acknowledge CNPq, FAPEMIG (PPSUS \#3336/06), FAPESP (\#2008/04371-5), CAPES and PROBIC-UNIFAL for financial support and fellowships. They are also grateful to Prof. Luzineide Tinoco of LAMAR-UFRJ Laboratory for the NMR spectra.

\section{References}

${ }^{1}$ Alzheimer's Society. Dementia is a global health timebomb. Disponível em: <http://www.alzheimers.org.uk/site/scripts/ press article.php?pressReleaselD=772>. Acesso em: 21 março 2015. 
${ }^{2}$ Giacobini, E.; G. Pepeu, G. The Brain Cholinergic System: in Health and Disease, 1. ed., Informa Healthcare, Oxon, 2006.

${ }^{3}$ Standaert, D. G.; Young, A. H. In: Treatment of Central Nervous System Degenerative Disorders. Goodman and Gilman's: The Pharmacological Basis of Therapeutics, 9a. ed.; McGraw Hill: New York, 1996.

${ }^{4}$ Giacobini, E. Cholinesterase inhibitors: from the calabar bean to Alzheimer therapy, In: E. Giacobini Cholinesterases and cholinesterase inhibitors, Martin Dunitz: London, 2000.

${ }^{5}$ Nordberg A.; Svensson A. L. Cholinesterase inhibitors in the treatment of Alzheimer's disease: a comparison of tolerability and pharmacology. Drug Safety 1998, 19, 465. [CrossRef] [PubMed]

${ }^{6}$ Racchi, M.; Mazzucchelli, M.; Porrello, E.; Lanni, C.; Govoni, S. Acetylcholinesterase inhibitors: novel activities of old molecules. Pharmacological Research 2004, 50, 441. [CrossRef] [PubMed]

${ }^{7}$ Neugroschl, J.; Sano, M. Current treatment and recent clinical research in Alzheimer's disease. Mount Sinai Journal of Medicine 2010, 77, 3. [CrossRef] [PubMed]

${ }^{8}$ Delagarza, V. W. Pharmacologic Treatment Of Alzheimer's Disease: An Update. American Family Physician 2003, 68, 1365. [PubMed]

${ }^{9}$ Geldmacher, D. S. Donepezil (Aricept) for treatment of Alzheimer's disease and other dementing conditions. Expert Review Neurotherapeutics 2004, 4, 5. [CrossRef] [PubMed]

${ }^{10}$ Dias, K. S. T.; Viegas Jr. C. Multi-Target Directed Drugs: A Modern Approach for Design of New Drugs for the treatment of Alzheimer's Disease. Current Neuropharmacology 2014, 1, 239. [CrossRef] [PubMed]

${ }^{11}$ Dias, K. S. T.; de Paula, C. T.; Riquiel, M. M.; Lago, S. T.; Costa, K. C. M.; Vaz, S. M.; Machado, R. P.; Lima, L. M. S.; Viegas Junior, C. Aplicações Recentes da Abordagem de Fármacos Multialvo para o Tratamento da Doença de Alzheimer. Revista Virtual de Química 2015, 7, 609. [CrossRef]
${ }^{12}$ Simões, M. C. R.; Viegas, F. P. D.; Moreira M. S.; de Freitas, M. S.; Riquiel, M. M.; Rosa, P. M.; Castelli, M. R.; dos Santos, M. H.; Soares, M. G.; Viegas Jr., C. Donepezil: an important prototype to the design of new drug candidates for Alzheimer's disease. Mini-Review in Medicinal Chemistry 2014, 14, 2. [CrossRef]

${ }^{13}$ Viegas Jr. C.; Nicastro, P. C.; Fossaluzza, P. C.; Gomes, C. P.; Santos, L. A.; Bolzani, V. S.; Pivatto, M.; da Silva, D. J. C.; Melo, G. M. A.; da Silva, Y. K. C.; Alexandre-Moreira, M. S.; da Costa, R. S.; Areas, T. F. M.; Castro, N. G. Structural modifications in (-)-cassine and LASSBio-767: strategies for the discovery and optimization of new drug candidates. Revista Virtual de Química 2009, 1, 117. [CrossRef]

${ }^{14}$ Viegas Jr. C.; Bolzani, V. S.; Castro, N. G.; Cabral, R. F.; Costa, R. S.; Floyd, C.; Rocha, M. S.; Young, M. C. M.; Barreiro, E. J.; Fraga, C. A. M. New selective acetylcholinesterase inhibitors designed from natural piperidine alkaloids. Bioorganic \& Medicinal Chemistry 2005, 13, 4184. [CrossRef] [PubMed]

${ }^{15}$ Castro, N. G.; Pimentel, L. S.; Danuello, A.; Romeiro, N. C.; Viegas Jr. C.; Barreiro, E. J.; Fraga, C. A. M.; Bolzani, V. S.; Rocha, M. S. CNS-selective noncompetitive cholinesterase inhibitors derived from the natural piperidine alkaloid (-)-spectalin. European Journal of Pharmacology 2008, 580, 339. [CrossRef] [PubMed]

${ }^{16}$ Miao, Y. Q.; Nongyue, H.; Zhu, J. J. History and New Developments of Assays for Cholinesterase Activity and Inhibition. Chemical Reviews 2010, 110, 5216. [CrossRef] [PubMed]

${ }^{17}$ Ellman, G. L.; Courtney, K. D.; Andres Jr. V.; Featherstone, M. A new and rapid colorimetric determination of acetylcholinesterase activity. Biochemical Pharmacology 1961, 7, 88. [CrossRef]

${ }^{18}$ Ingkaninan, K.; de Best, C. M.; Van der Heijden, R.; Hofte, A. J. P.; Karabatak, B.; Irthb, H.; Tjaden, U. R.; Van der Greef, J.; Verpoorte, R. High-performance liquid chromatography with on-line coupled UV, mass spectrometric and biochemical 
detection for identification of acetylcholinesterase inhibitors from natural products. Journal of Chromatography A 2000, 872, 61. [CrossRef]

${ }^{19}$ Martin-Biosca, Y.; Asensi-Bernardi, L.; Villanueva-Camañas, R. M.; Sagrado, S.; Medina-Hernández, M. J. Scrrening of acetylcholinesterase inhibitors by CE after enzymatic reaction at capillary inlet. Journal of Separation Science 2009, 32, 1748. [CrossRef] [PubMed]

${ }^{20}$ Min, W.; Wang, W.; Chen, J.; Wang, A.; Hu, Z. On-line immobilized acetylcholinesterase microreactor for screening of inhibitors from natural extracts by capillary electrophoresis. Analitycal and Bioanalalytical Chemistry 2012, 404, 2397. [CrossRef] [PubMed]

${ }^{21}$ Andrisano, A.; Bartolini, M.; Gotti, R.; Cavrini, V.; Felix, G. Determination of inhibitors' potency $\left(\mathrm{IC}_{50}\right)$ by a direct highperformance liquid chromatographic method on an immobilised acetylcholinesterase column. Journal of Chromatography B 2001, 753, 375. [CrossRef]

${ }^{22}$ da Silva, J. I.; Moraes, M. C.; Vieira, L. C. C.; Corrêa, A. G.; Cass, Q. B.; Cardoso, C. L. Acetylcholinesterase capillary enzyme reactor for screening and characterization of selective inhibitors. Journal of Pharmaceutical and Biochemical Analysis 2013, 73, 44. [CrossRef] [PubMed]

${ }^{23}$ Tümtürk, H.; Şahin, F.; Demirel, G. A new method for immobilization of acetylcholinesterase, Bioprocess Biosystems Enginneering 2007, 30, 141. [CrossRef] [PubMed]

${ }^{24}$ Bartolini, M.; Greig, N. H.; Yu, Q. S.; Andrisano, $\quad \mathrm{V}$ Immobilized butyrylcholinesterase in the characterization of new inhibitors that could ease Alzheimer's disease. Journal of Chromatography A 2009, 1216, 2730. [CrossRef]

${ }^{25}$ Bartolini, M.; Cavrini, V.; Andrisano, V. Choosing the right chromatographic support in making a new acetylcholinesterase-microimmobilised enzyme reactor for drug discovery. Journal of Chromatography $A$ 2005, 1065, 135. [CrossRef] [PubMed]

${ }^{26}$ Doong, R. A.; Tsai, H. C. Immobilization and characterization of sol-gel-encapsulated acetylcholinesterase fiber-optic biosensor. Analytica Chimica Acta 2001, 434, 239. [CrossRef]

${ }^{27}$ Bartolini, M.; Cavrini, V.; Andrisano, V. Characterization of reversible and pseudoirreversible acetylcholinesterase inhibitors by means of an immobilized enzyme reator. Journal of Chromatography A 2007, 1144, 102. [CrossRef] [PubMed]

${ }^{28}$ Bartolini, M.; Cavrini, V.; Andrisano, V. Monolithic micro-immobilized-enzyme reactor with human recombinant acetylcholinesterase for on-line inhibition studies. Journal Chromatography A 2004, 1031, 27. [CrossRef] [PubMed]

${ }^{29}$ Gabrovska, K.; Nedelcheva, T.; Godjevargova, T.; Stoilova, O.; Nanolova, N.; Rashkov, I. Immobilization of acetylcholinesterase on new modified acrylonitrile copolymer membranes. Journal of Molecular Catalalysis B 2008, 55, 169. [CrossRef]

${ }^{30}$ Forsberg, E. M.; Gree, J. R.; Brennan, J. D. Continuous flow Immobilized Enzyme Reactor-Tamdem Mass Spectrometry for screening of AChE Inhibitors in Complex Mixtures. Analytical Chemistry 2011, 83, 5230. [CrossRef] [PubMed]

${ }^{31}$ Vanzolini, K. L.; Vieira, L. C. C.; Corrêa, A. G.; Cardoso, C. L.; Cass, Q. B. Acetylcholinesterase immobilized capillary reactors-tandem mass spectrometry: an onflow tool for ligand screening. Journal of Medicinal Chemistry 2013, 56, 2038. [CrossRef] [PubMed]

${ }^{32}$ Viegas Jr. C.; Bolzani, V. C.; Pimentel, L. S.; Castro, N. G.; Cabral, R. F.; Costa, R. S.; Floyd, C.; Rocha, M. S.; Young, M. C.; Barreiro, E. J.; Fraga, C. A. New selective acetylcholinesterase inhibitors designed from natural piperidine alkaloids. Bioorganic and Medicinal Chemistry 2005, 13, 4184. [CrossRef] 
${ }^{33}$ Marston, A.; Kissling, J.; Hostettmann, K. A Rapid TLC Bioautographic Method for the Detection of Acetylcholinesterase and Butyrylcholinesterase Inhibitors in Plants. Phytochemical Analysis 2002, 13, 51. [CrossRef] [PubMed]

${ }^{34}$ Rhee, I. K.; Van Rijin, R. M.; Verpoorte, R. Qualitative determination of false positive effects in the acetylcholinesterase assay using thin layer chromatography. Phytochemical Analysis 2003, 14, 127. [CrossRef] [PubMed]

${ }^{35}$ Buenger, J.; Ackermann, H.; Jentzsch, A.; Mehling, A.; Pfitzner, I.; Reiffen, K. A.; Schroeder, K. R.; Wollenweber, U. An interlaboratory comparison of methods used to assess antioxidant potentials. Internacional Journal of Cosmetic Science 2006, 28, 135. [CrossRef] [PubMed]

${ }^{36}$ Lam, K. S. New aspects of natural products in drug discovery. Trends in Microbiology 2007, 15, 279. [CrossRef] [PubMed]
${ }^{37}$ Di, L.; Kerns, E. H.; Li, S. Q.; Carter, G. T. Comparison of cytochrome $\mathrm{P} 450$ inhibition assays for drug discovery using human liver microsomes with LC-MS, rhCYP450 isozymes with fluorescence, and double cocktail with LC-MS. Internacional Journal of Pharmaceutics 2007, 335, 1. [CrossRef] [PubMed]

${ }^{38}$ Kryger, G. I. S.; Sussman, L. S. Structure of acetylcholinesterase complexed with E2020 (Aricept $\left.{ }^{\circledast}\right)$ : implications for the design of new anti-Alzheimer drugs. Structure 1999, 7, 297. [CrossRef]

${ }^{39}$ Rhee, I. K.; Apples, N.; Luijendijk, T.; Irth, $\mathrm{H}$. ; Verpoorte, R. Determining Acetylcholinesterase Inhibitory Activity in Plant Extracts Using a Fluorimetric Flow Assay. Phytochemical Analysis 2003, 14, 145. [CrossRef] [PubMed] 